INTERnational JOURNAL OF MULtidisciplinaRy Research AND ANALysis

ISSN(print): 2643-9840, ISSN(online): 2643-9875

Volume 04 Issue 01 January 2021

DOI: 10.47191/ijmra/v4-i1-10, Impact Factor: 5.522

Page No.- 64-67

\title{
Structural Directions of National Development Models of Uzbekistan and Russia
}

\author{
Fazliddin Ravshanov ${ }^{1}$, Bekzod Baratbaev ${ }^{2}$ \\ ${ }^{1}$ DSc, Professor, Department of Civil Society and Law, National University of Uzbekistan, Tashkent, Uzbekistan \\ ${ }^{2}$ Independent researcher, Department of Civil Society and Law, National University of Uzbekistan Tashkent, Uzbekistan \\ ORCID: 0000-0002-1688-4918
}

ABSTRACT: Each country's national development model is unique and covers its current and future goals and interests. Both in Uzbekistan and in Russia, one can see that the concepts of national development are expressed in terms of decisions, decrees, instructions, programs, regulations, plans, strategies, as mentioned above. The article provides a comparative analysis of the structural aspects of these concepts, processes and events taking place on their basis.

KEYWORDS: national development model, concept, "Action Strategy”, "Government Order”, national development ideas

\section{INTRODUCTION}

Each country's national development model is unique and covers its current and future goals and interests. Organization of activities and implementation of plans in these areas will lead to the formation of legal documents in various forms, such as decisions, decrees, instructions, programs, regulations, plans, strategies. In both Uzbekistan and Russia, it can be seen that the concepts of national development are expressed in terms of decisions, decrees, instructions, programs, regulations, plans, strategies, as mentioned above. All of these have their own theoretical definitions as scientific categories. But in practice, many of them exhibit a conceptual character. In fact, the legal significance of such documents stems from the need to control the quality, timeliness and effectiveness of the funds allocated for them, the goals and objectives set. Accordingly, concepts are becoming increasingly important in strategic planning processes in many countries today.

\section{MATERIALS AND METHODS}

Over the years, Uzbekistan [1] and Russia [2] have adopted a number of relevant documents, some of which are directly aimed at national development goals, while others are indirect, ie, cover specific areas of development plans and include concepts in the document. . Below we compare two concepts focused on the goals and interests of nationwide national development.

\section{RESULTS}

It is known that in 2017, the Decree of the President of the Republic of Uzbekistan "On the Strategy of Actions for the Further Development of the Republic of Uzbekistan" (abbreviated "Action Strategy") was adopted. Although the document is called the strategy of action, it corresponds to the content of the concept in terms of duration, focus areas, goals and interests, subjects and objects of execution, political, economic, legal and other constructive principles, set of ideas and their activation. Although the appendix reveals the multifaceted objectives of the "Action Strategy for the five priority areas of development of the Republic of Uzbekistan in 2017-2021", together with the Decree, the concept consists of 9 components, which clearly reflect the term, structural areas, goals, subjects and objects of implementation, a set of ideas in accordance with the requirements of the concept. The rest of the essence is represented in the mentioned applications.

In Russia, one of such concepts was the Decree of the Government of the Russian Federation "On the Concept of long-term socio-economic development of the Russian Federation until 2020" (abbreviated as "Government Decree") in 2008. Although this document has the appearance of a government order, its content and structure are fully consistent with the structure of the concepts. Earlier, the Ministry of Regional Development of the Russian Federation had developed a number of strategic planning 


\section{Structural Directions of National Development Models of Uzbekistan and Russia}

documents. They are called by different names: development strategy, strategic concept, schemes of deployment of productive forces, development programs, strategic plans. However, the quality of many such adopted regional documents did not meet the conceptual requirements [3].

Both concepts first provide a brief overview of the work done to organize national development in the period prior to their adoption. This allowed the society to visualize the current or newly introduced directions of national development, to trace the order and dynamics of processes and, accordingly, the democratic level of the policy being pursued. The difference is that in the action strategy, the summary is expressed in the decree only by counting the names of the work done, and in the state order it is indicated with a brief description of the work done. In this regard, although the state order is more complete than an action strategy, both summaries leave no opportunity to assess the dynamics of the effectiveness of the work done over the past period. However, the concept should assess the performance level of the area or system of industries in which it is applied before it takes effect, and allow us to understand whether the next steps described in the concept are relevant in terms of goals and interests.

A second important component specific to the concept in the Action Strategy and Government Order is the question of the purpose of the concept. In the strategy of action, the main objectives of this concept are directly expressed in the structure of the decree and generalized as a summary, ie: "Improving the effectiveness of ongoing reforms, creating conditions for the comprehensive and rapid development of the state and society, the implementation of priorities for the modernization of our country and the liberalization of all spheres of life".

The government decree states that this goal is included in the concept, "to achieve a level of economic and social development of Russia in the XXI century, which will take the lead in global economic competition and ensure national security and the constitutional rights of citizens". Russia's entry into the top five countries in terms of GDP (purchasing power parity) in 2015-2020 means that by the end of the next decade, a qualitatively new image of Russia will emerge in the future".

The interest-related aspects of the concept are reflected in the Action Strategy in part as part of the priorities reflected in the Decree. Relatively detailed are described in the appendices. The government decree pays special attention to the issue of representation of interests, which is expressed in the concept as a separate "order" of society to the subjects [4].

The timelines for the implementation of the concept are set out in both the formal and conceptual parts of both documents. Some experts consider it expedient that term indicators should be expressed only in the concept, depending on whether there is a possibility to implement the conceptual goal and interests in full and in excess. That is, its expression in a formal decree or order dramatically increases the strict responsibilities and obligations of the subjects in a way incompatible with their capabilities, which, on the one hand, contradicts the principles of generalization of conceptual interests on the basis of social freedom; [5], which can eventually lead to the development of vices such as fraud, duplication, and corruption. Others, on the contrary, argue that their being within formal requirements is also necessary to increase accountability and commitment.

Both the Action Strategy and the State Order reflect multi-sectoral and cross-sectoral directions. They are listed as priorities reflecting national development, their components and sectoral ideas expressed in the component paragraphs. The difference is that in the Action Strategy, a number of components and sectoral ideas are firmly defined in the form of tasks [6]. In the government decree, almost all components and sectoral issues are listed as ideas, and it is recognized that the results achieved on them will be determined in a timely manner in comparison with domestic or international levels. In some cases, the concept plans are manifested in the form of laws of the subjects of the Federation, in others - orders and decisions of regional executive bodies, in third - decrees of the governor, in fourth - decisions of regional legislatures. Only by 2018 have they been brought into line with the basic concept [7].

\section{DISCUSSION}

According to a number of Russian analysts, the Government's decree has created a strong motivation for the implementation of reforms aimed at introducing an efficiency management system due to the current sluggish budget and economic conditions in the implementation of national development [8]. At the same time, the concept of long-term socio-economic development of the Russian Federation until 2020, developed in 2008, is considered "the first serious attempt by the Government of the Russian Federation to formulate a strategic document"[9]. However, as some experts rightly point out, this document does not contain a clear agreement on the conceptual planning of national development and the corresponding budget allocation [10]. At this stage in the evolution of conceptual planning for national development, the success of the federal government manifested itself primarily in the adoption of a unifying legal document. Similarly, in Russia, this concept has been developed in federal districts and industry agencies based on the needs and requirements of the region and industry in terms of its composition. As a result, more than 2,000 concepts were adopted by region and sector.

The same can be said about the Action Strategy of Uzbekistan, where more than 1,000 concepts and "road maps" have been developed in the country by the relevant structures and organizations on the priorities, components and items of this 


\section{Structural Directions of National Development Models of Uzbekistan and Russia}

document. However, one of the most important aspects of the Action Strategy is that its five-year plans for its implementation are clearly stated in the annual State Programs and that the implementation of the tasks has a clear structure. Simply put, the organizations and individuals responsible for the implementation of each plan set out in this concept of national development, the implementation of the set finances and deadlines actually create an effective system for achieving goals.

\section{CONCLUSION}

In short, each of these concepts has its own advantages, which makes it possible to systematize many emerging processes and events in accordance with their structural directions. This is very important for understanding and assessing the contradictions that arise in the process of hierarchical systematization of managerial decision-making in the framework of strategic planning. Second, each of the stages in the evolution of modern strategic planning identified in the concepts has its own characteristics. However, there are significant differences in the strategic approaches of the concept components in terms of strategic planning and time coordinates: this difference is reflected in the "Relying on and Following the Directions of the Action Strategy" and "Copying the Norms of the Federal Central Concept Taking into account Regional Features". Third, the priorities of the Action Strategy, their components and items allow to substantiate national models by analyzing and summarizing the content of national development plans, setting goals and objectives, achieving the results of socio-economic development. The Russian concept has a significant positive impact on the internal and external factors of strategic planning in federal districts and key sectors of the national economy, which makes it possible to timely update both the strategic documents themselves and their legal status.

\section{REFERENCES}

1) Ўзбекистон Республикаси Вазирлар Махкамасининг Қарори. Ахолига коммунал хизмат кўрсатиш тизимида иқтисодий ислохотларни чуқурлаштириш концепциясини тасдиқлаш тўғрисида 1998 йил 3 ноябрь, 461-сон. https://lex.uz/ru/docs/802905; Ўзбекистон Республикаси Вазирлар Махкамасининг Қарори. Давлат ва хўжалик бошқаруви органларининг виртуал маконда иштирокини фаоллаштириш концепциясини тасдиқлаш тўғрисида 2018 йил 7 август, 622-coн. https://www.lex.uz/ru/docs/3855599; Ўзбекистон Республикаси Президентининг Фармони. Қишлоқ хўжалигида ер ва сув ресурсларидан самарали фойдаланиш чора-тадбирлари тўғрисида 2019 йил 17 июнь, ПФ-5742-сон. https://lex.uz/docs/4378526; Ўзбекистон Республикаси Президентининг қарори. Ўзбекистон Республикаси мактабгача таълим тизимини 2030 йилгача ривожлантириш концепциясини тасдиқлаш тўғрисида. https://www.pv.uz/uz/documents/

2) Ravshanov, F. (2018). Tolerance: history and development. The Light of Islam, 2018(1), 17.

3) Azimov, H. Y. (2019). The emergence of the syrian crisis and the impact of the external forces on it. Bulletin SocialEconomic and Humanitarian Research, (4), 92-97.

4) О совершенствовании разработки, утверждения и реализации программ экономического и социального развития субъектов РФ. Приказ М-ва экон. развития и торговли РФ от 17.06.2002 № 170. http://base.garant.ru/1590458

5) Ravshanovich, R. F., Tuigunovich, R. F., \& Yakubovich, A. H. (2020). Amir Temur and Turan States. Bulletin Social-Economic and Humanitarian Research, (5 (7)).

6) Azimov, H. Y. (2019). THE PROBLEM OF MORO MUSLIMS. Theoretical \& Applied Science, (6), 519-521.

7) Шеломенцев А. Г., Дорошенко С. В., Трушкова Е. А., Шихвердиев А. П. Стратегии-2030: подходы к разработке в регионах России // Ars Administrandi (Искусство управления). 2017. Том 9, № 4. С. 570-592.

8) Ravshanov, F. (2019). STAGES OF HISTORICAL DEVELOPMENT OF THE SYSTEM OF SELECTION OF LEADING PERSONNEL IN CENTRAL ASIA. The Light of Islam, 2019(4), 22.

9) Равшанов, Ф. (2007). Миллий рахбаршунослик: тарих ва тажриба.

10) Азимов, Х. Я. (2020). Сурия инқирози даврида Туркия-Россия муносабатлар. Imom Buxoriy saboqlari, 1(2), 86-88.

11) Ravshanov, F. R. Tolerancy and perspectives of development.

12) Азимов, Х. Я. (2020). Кашмир муаммоси: тарих ва бугун. ҚардУ Хабарлари, 1(1), 180-185.

13) Ravshanov, F. R. (2020). Abu Nasr Farabi on the harmony of society, politics and law. ISJ Theoretical \& Applied Science, 02 (82), 401-407.

14) Azimov, H.Y. (2021). The kurdish factor in Turkish-Syrian relations until the "Arab spring". VII Международной научноПраКтИчесКОЙ КОНфереНциИ АКТУАЛЬНЫЕ ВОПРОСЫ СОВРЕМЕННОЙ НАУКИ И ОБРАЗОВАНИЯ.

15) Равшанов, Ф. (2019). Этапи развития государства: теория и практика.

16) Распоряжение Правительства РФ от 17.11.2008 Н 1662-р (ред. от 28.09.2018) “О Концепции долгосрочного социально-экономического развития Российской Федерации на период до 2020 года" 


\section{Structural Directions of National Development Models of Uzbekistan and Russia}

17) 5.Национальная идея России.Под общей редакцией С.С. Сулакшина В 6 т. Т. І. - М.: Научный эксперт, $2012 .-$. 75.

18) Madaminova, D. (2020). MIGRATION PROCESS AND PROBLEMS IN NORTH AFRICA AND THE MIDDLE EAST. In ОБЩЕСТВЕННЫЕ НАУКИ В СОВРЕМЕННОМ МИРЕ: ПОЛИТОЛОГИЯ, СОЦИОЛОГИЯ, ФИЛОСОФИЯ, ИСТОРИЯ (рР. 80-85).

19) Акрамов Ж.Д. Харакатлар стратегияси Ўзбекистонда давлат бошқарувини модернизациялашнинг бош сиёсийхуқуқий мезони сифатида. http://tsue.uz/wp-content/uploads/2019/10/34.

20) Iskandarovna, M. D. (2019). Factors affecting the development of migration flows and measures taken by European countries to address the problem. Asian Journal of Multidimensional Research (AJMR), 8(3), 133-136.

21) Шеломенцев А. Г., Дорошенко С. В., Трушкова Е. А., Шихвердиев А. П. Стратегии-2030: подходы к разработке в регионах России // Ars Administrandi (Искусство управления). 2017. Том 9, № 4. С. 570-592.

22) Гусарова М. В., Овчинникова М. А. Управление по результатам в системе государственного управления в России: подходы и результаты реформирования за последние 10 лет // Вопросы государственного и муниципального управления. 2019. № 1. С. 98-126.

23) Cooper J. Reviewing Russian strategic planning: the emergence of Strategy 2020 // NATO Defense College Research Review. 2012. http://www.ndc.nato.int/download/downloads.php?icode=338. 